Klassikern:

\title{
OM FRILUFTSMUSEER OCH BYGDEMUSEER I SKANDINAVIEN 1930
}

\section{Marc Bloch}

Marc Bloch (1886-1944), den berömde franske historikern, ledare för Annalesskolan, forfattare till det klassiska arbetet om feodalismen, 'La societé féodale' (1939-40), medlem av den franska motståndsrörelsen och avrättad av ockupationsmakten, gjorde 1930 en resa till Skandinavien, där han bl a lärde känna Anders Sandvig, Olav Midttun, Jan Petersen och Sigurd Grieg i Norge, samt Viggo Bröndal i Danmark. De skandinaviska friluftsmuseerna gjorde starkt intryck och han skildrade dem i foljande tidskriftsartikel.

För att på ett rättvist sätt behandla de nordiska friluftsmuseerna, vore det nödvändigt att ha en grundlig kunskap om de skandinaviska kulturformer som de är ett så pregnant uttryck för, såväl till själva sin idé som genom det de visar. Jag var några dagar gäst vid en stor norsk institution och passerade som turist på genomresa Stockholm och Köpenhamn och kan därför återge blott några hastiga reseintryck. Men det är omöjligt motstå impulsen att ändå berätta om dessa museiinitiativ som förtjänar att uppmärksammas av alla.

Föreställ er ett stort område med träd och grönska. I lövverket skymtar timrade byggnader, ibland i närheten av en lantlig kyrka. Här finns talrika allmogebyggnader med sina stabur (förrådshus för livsmedel), logar, fähus. Var och en exempel på en typ det kan vara åldern som skiljer dem åt, eller innehavarens sociala ställning: här prästgården, mer än till hälften "borgerlig", där storbondens gård, åter på ett annat ställe husmannens torftiga boning (han som samtidigt var torpare och daglönare) - men framför allt rör det sig om regionala skillnader i byggnadsskicket. I varje rum möter en passande möblering, som antingen följt med huset eller hämtats från en motsvarande miljö. Ingenting upplevs som en rekonstruktion - allt har hämtats på plats, har bit för bit transporterats från sin ursprungsmiljö till en fristad i friluftsmuseet.

Sådant ter sig friluftsmuseet, alltid likartat i sina huvuddrag, men i detaljer oändligt varierat. Först mötte jag det på den höjd som dominerar Stockholm med dess byggnader, parker och 'de muntra vattnens lek’: alltså Skansen, så kär för Nils Holgerssons läsare. Därefter på en halvö mittemot Oslo: Bygdöy, som sköljs av fjordens vatten, med dess Folkemuseum. Vid Lyngby det danska Frilandsmuseet mitt på den själländska slättbygden och slutligen Sandvigs samlinger, i det inre av Norge, nära Lillehammer vid Gudbrandsdalens mynning, där snön hade fallit tidigt. Dessutom finns otvivelaktigt - ty driften till museigrundande har här i norr överallt varit $\mathrm{i}$ grunden densamma - mer än en anläggning 
74 av det här slaget i varje region, välbekanta för specialister och landets eget folk, men platser som den jäktade resenären tvingas avstå från att besöka.

Önskvärt vore att vi en dag hade en skrift som kunde skildra dessa museers historia till sin art så långt från den föreställning om något dött och dammigt som ordet museum vanligtvis framkallar hos oss - från deras förfader - Skansen, eller hur?, det idag rikaste - till de alldeles nyligen tillkomna. Vilket ljus skulle inte en sådan skildring kasta över idéernas och sentimentets utveckling i de tre nordiska länderna, vilka rörande episoder skulle inte återkallas i minnet!

Här till exempel. För ett fyrtiotal år sedan slog sig en ung tandläkare, A Sandvig, ner i Lillehammer, en liten vänlig stad, dit ryktet om ett hälsosamt klimat lockat honom. Han fängslades av Gudbrandsdalens gamla allmogeföremål och började tålmodigt samla dem. Väl att märka: på egen bekostnad: de första byggnader som han räddar från förstörelse återuppför han i sin egen trädgård, till stor del med egna händer. Senare får han hjälp och åtnjuter en växande berömmelse. Utan att lämna det yrke, som ger honom hans levebröd, har han nu också blivit direktör för ett museum, varöver hela Norge känner stolthet. För att få plats för samlingarna, som växer varje år, men hela tiden klokt begränsas till Gudbrandsdalen, har han i det närliggande skogsområdet kunnat förvärva en del av sluttningen ner mot dalen. Där härskar han över en sannskyldig, skickligt inkomponerad, trästad. Med vilken utsökt smak, vilken i bästa mening poetisk känsla för det samband som kan uppstå mellan människans arbete och naturen, har han inte åstadkommit detta! Därom kan alla vittna, som i det ble- ka ljuset däruppe vandrat omkring den lilla dammen, bland de vackert bruna timmerhusen. Men husgrupperna har inte bara till syfte att glädja ögat. De är rika på all slags information, så varierad och uttömmande att många sidor skulle krävas endast för att ge ett första intryck. Jag måste nöja mig med några hastiga exempel.

Den tekniska utvecklingen. När man går från det ena huset till det andra, avtecknar sig hela eldstadens historia i Norge: från den öppna mitthärden under en rököppning i taket till hörnspisen med skorsten. Den kallas här peis, (det är vulgärlatinets pesile - vad avslöjar inte språket om kulturkontakter!) och är välbekant för alla turister. Jag förbigår här alla varianter och mellanformer - de som införts av finska invandrare; spisarna av glaserat tegel eller gjutjärn, som importerats från Tyskland eller Holland eller är imitationer av sådana.

Det religiösa livet och mentala arvet. Vilka egendomliga problem erbjuder inte 1600talskyrkorna för reformationens historiker, kyrkor, vilkas utsmyckning vi vanligtvis förknippar med den katolska helgedomen. Och folktron - vilka glädjeämnen som finns i så många ting, vittnesbörd om den mest naiva och långlivade övertro. Så dessa trästolar från Telemarken fulla med islagna mjölktänder: de som satte sig $\mathrm{i}$ en sådan behövde inte frukta för att fă värk i sina egna tänder!

Socialhistoria. Som den avtecknar sig i själva husens dimensioner, deras antal och rummens möblering. De särskilda husen för de gamla och gästerna; de olika sederna för pigors och drängars inkvartering tillsammans med, eller skilda från, ägarens egna barn. Alla dessa vardagsfakta, på ett lämpligt sätt förmedlade och belysta av andra vittnemål - vilka lektioner erbjuder de inte om 
familjen, klasserna, högtiderna, själva rytmen och strukturen i det kollektiva livet!

Kulturkontakterna. Se hur i vår egen tid långsamt, tafatt, men säkert, den klassiska stilens former vinner insteg i möblernas form och utsmyckning, i textilierna och i byggnadernas arkitektur. Ibland kan man avgöra på vilka vägar den nya smaken, född under varmare luftstreck, har nått till denna avlägsna Nord - i denna dalgång till exempel, genom påverkan från de gruvarbetare som kallats in från Tyskland.

Vid sidan av husen - redskapen. Låt oss återvända till Lillehammer. På toppen av den höjd, där friluftsmuseet ligger, finns en långsträckt byggnad, där varje rum är en hantverkares verkstad, utrustad på gammalt sätt. I några av dem en levande hantverkare - det är inte ägnat att förvåna att han nästan alltid är vithårig - som arbetar på sitt sätt som inte $\mathrm{i}$ något avseende är dagens. Ett levande museum om något, där kunskapen förmedlas i själva handgreppen. Det handlar här - det måste medges - om yrken som även om de utövats på landet, är välkända också utanför den rurala miljön.

Men av ett landsbygdsmuseum väntar vi oss naturligtvis framför allt att få kunskap om jordbrukets teknik. Den saknas heller inte någonstans. I Lillehammer visar en av de stora gårdarna en hel provkarta på jordbruksredskap. I Lyngby, på Bygdöy, finns rika specialsamlingar av odlingsredskap i särskilda byggnader, och sådana finns uppenbarligen också i andra museer som jag inte kunnat besöka eller där jag gjort alltför korta besök.

Kanske jag ändå här för första gången vågar påpeka en brist? Hur lärorika sådana lantbruksmuseer än kan vara - och jag har själv dragit viktiga lärdomar ur dem - så synes de mig ännu inte ha utvecklat hela sin potential. Det är fallet när det gäller åtminstone då de, i ordets egentliga bemärkelse passerat den gräns som skiljer historia från förhistoria. Konsten att klassificera och datera redskapsformer har av den förhistoriska arkeologin bragts till en sällsynt fulländning. Men medeltidsarkeologin, liksom det historiska föremålsstudiet, är nästan enbart estetisk. Museimannen som känner sig hemma inför en tavla, vet inför en plog eller spinnrock ofta inte hur han skall bete sig. Det är naturligt att han är benägen betrakta allt som en sorts bakgrund, som bara kan användas för att skapa atmosfär eller ge lokalfärg. Eller, om han själv är tekniker snarare än arkeolog, knyter sig intresset särskilt till de senaste förbättringarna.

Uppgiften är - det kan inte förnekas ovanligt krävande. Det är trots allt mindre problematiskt att $\mathrm{i}$ en kronologisk serie placera in en yxa av kvarts eller diabas, med den i detta fall tillåtna approximationen, än att med den precision som därvidlag är nödvändig datera ett årder, en harv eller en vävstol. Det är hela teknikhistoriens problem som museer av detta slag aktualiserar, ty där måste liksom annorstädes, tingens anordning i utställningssalarna och deras teoretiska studium ske parallellt. Hela denna fråga är alltför viktig för att kunna behandlas på några få rader och därtill krävs för övrigt någon mera kompetent än jag. Åtminstone kunde vi kräva att ett redskap vilket som helst aldrig ställdes ut utan att dess sociala innebörd klart och tydligt angavs, på samma sätt som uppgifterna om ett stenåldersfynd.

Låt oss nu ägna oss åt självprövning. Vi har också i Frankrike regionmuseer, många mycket vackra. Hur skulle en Strassbourgbo kunna glömma Musée alsacien? Varför 
76 inte påminna om den nyprovencalska rörelsen som gett upphov till Musée Arlaten? Men utom att dessa museer i sina salar ger plats åt rika folkliga föremålssamlingar, förblir de dock i grunden urbana företeelser. Det är i rummen i borgerliga byggnader eller palats som dessa lantliga ting ställs ut; hemlösa påminner de om en arbetare $\mathrm{i}$ träskor som hamnat $\mathrm{i}$ en salong. Här och där erbjuds vi några rumsinredningar, mer eller mindre konstlat sammanförda. Ingenstädes får man se dem i deras naturliga inramning, som inte skulle kunna vara annat än ett friluftsmuseum, där hela byggnader förts samman. Än mer sällan upplever man att en rimlig ansträngning gjorts för att klassificera företeelserna - hus eller ting - efter tid och kategori. Vad man erbjuder oss är något pittoreskt, där för övrigt ju ändå själva landskapet saknas! Utan tvivel vore det utopiskt att sträva efter att hos oss transplantera dessa bygdemuseer från Norden. De är födda ur platsen och den speciella nationalkänslan. De psykologiska förutsättningarna åsido: denna djupt rotade, nästan hedniska, känsla för naturen, som i Skandinavien under den kristna och protestantiska ytan ofta gör intryck av att vara en relikt från svunna tider, denna drift att vidmakthålla eller återuppliva landets äldsta traditioner, som där inte är ett ytligt eko från romantiken utan alldeles direkt - särskilt i Norge - ett uttryck för en fundamental nationalkänsla och ibland även för en demokratisk instinkt. Låt oss för enkelhetens skull begränsa oss till mer konkreta frågor. Att förvärva ett stycke skogs- eller ängsmark är i Norge och Sverige åtminstone en relativt överkomlig uppgift och otvivelaktigt jämförelsevis rimligt betungande: för museet i franska Beauce skulle det vara mer bekymmersamt. Nästan överallt i
Skandinavien (med undantag av Danmark) är det folkliga byggnadsskickets material timmer: att ta ner ett hus och återuppföra det är i grunden en föga komplicerad uppgift. Nästan överallt (återigen är Danmark ett undantag) har också bondesamhällets traditioner bevarats, särskilt $i$ vissa avlägsna dalgångar, med en trohet och renhet som knappast har någon motsvarighet hos oss. Inte ens Bretagne eller Central-massivet skulle kunna ge ett motsvarande intryck. Traditionen är inte bara nära, ofta lever den ännu med sin egen teknologi, sin uråldriga dekor - alldeles färdig att flyttas in i ett museum.

Jag är angelägen om att beröra svårigheterna. De är allvarliga och leder tvivelsutan till slutsatsen att man måste anpassa snarare än bara efterhärma det nordiska exemplet. Men det förefaller mig omöjligt att förbli likgiltig. Se för övrigt på Danmark - trots att där rurala mönster möter, som är mycket lika dem som slagit igenom över hela det nordeuropeiska slättområdet, så har danskarna vetat att tillägna sig och anpassa det väsentliga $\mathrm{i}$ friluftsmuseitanken som ursprungligen uppstått $\mathrm{i}$ länder med helt olikartat jordbruk. Hos oss tillkommer det ledarna för landsortsmuseerna, medlemmar och inspiratörer i regionala historiska föreningar att överväga möjligheten att ta upp idén - det är dem jag tillägnar de iakttagelser jag här återgivit!

Artikeln finns publicerad i 'Les Annales d'histoire économique et sociale', 1930, vol 2, no 6. Marc Maure har visat oss på den och har haft vänligheten granska översättningen av P-U Ågren. Den franska texten återfinns omtryckt $i$ anslutning till Marc Maures 'Nation, paysan et musée. La naissance des musées d'ethnographie dans les pays scandinaves (1870-1904)' i tidskriften TERRAIN 20, mars 1993, pp 147-157. 